\title{
Zmiany struktury przestrzennej przemysłu samochodowego Brazylii na przełomie XX i XXI wieku
}

\section{Changes in the spatial structure of the automotive industry in Brazil at the turn of the 20th and 21 st century}

\begin{abstract}
Streszczenie: Przemysł samochodowy w Brazylii przeszedł w ostatnich dekadach głęboką transformację związaną z unowocześnieniem produkcji, podniesieniem efektywności oraz jakości produkowanych pojazdów. Procesy te zachodziły w sytuacji postępującej liberalizacji gospodarki, integracji regionalnej w obrębie Mercosur oraz globalizacji. Wysokie tempo wzrostu gospodarczego i stabilna sytuacja w kraju przyczyniły się do dynamicznego wzrostu zapotrzebowania na nowe pojazdy, za czym próbowały nadążyć miejscowe fabryki, notujące co roku nowe rekordy produkcji. Ten dynamiczny wzrost sprzedaży na krajowym rynku oraz w sąsiednich państwach skłonił międzynarodowe koncerny do dalszych inwestycji rozbudowujących moce produkcyjne brazylijskich fabryk motoryzacyjnych. Nowe inwestycje napływające do Brazylii diametralnie zmieniły przestrzenną strukturę przemysłu motoryzacyjnego. Na początku lat 90 . XX wieku $75 \%$ produkcji samochodów pochodziło ze stanu São Paulo, natomiast w 2012 roku jego udział w tym przemyśle zmalał do 41,5\%. Pojawiły się nowe centra produkcyjne w stanach: Parana, Bahía, Rio Grande do Sul czy Rio de Janeiro, a dalsze inwestycje w nowych lokalizacjach są w trakcie realizacji. Celem artykułu jest określenie zmian struktury przestrzennej przemysłu samochodowego w Brazylii w latach 1996-2011 oraz próba określenia, czy i gdzie powstały nowe skupienia tego przemysłu.
\end{abstract}

\begin{abstract}
In recent decades, the automotive industry in Brazil has undergone a profound transformation connected with the modernization of production, increase in the efficiency and quality of produced vehicles. These processes took place in a situation of progressive liberalization of the economy, regional integration within Mercosur and globalization. The high rate of economic growth and stability in the country contributed to the rapid growth in demand for new vehicles. Local factories struggled to keep up with the rising demand and have noted the new production records each year. The rapid growth of sales on the domestic market and in the neighboring countries has prompted international companies to further investments to expand production capacity in Brazilian car factories. New foreign investments arriving in Brazil radically changed the spatial structure of the automotive industry. In the early 1990s, $75 \%$ of the cars came from the state of São Paulo, whereas in 2012, its share fell to 41.5\%. The new production centers appeared in the states of Parana, Bahia, Rio Grande do Sul, Rio de Janeiro, and further investments are in progress. The purpose of this article is to determine the changes in the
\end{abstract}


spatial structure of the automobile industry in Brazil in the period 1996-2011. Furthermore, the author attempts to determine whether the investments made in the last two decades led to the emergence of new spatial agglomerations of the automotive industry.

Słowa kluczowe: Brazylia; koncentracja przestrzenna; Mercosur; przemysł samochodwy; współczynnik lokalizacji

Keywords: Brazil; spatial concentration; Mercosur; automotive industry; location coefficient

\section{W STĘP}

Ostatnie dwie dekady to bardzo ważny okres przemian i rozwoju brazylijskiego przemysłu motoryzacyjnego. Wraz z liberalizacją handlu międzynarodowego na początku lat 90 . XX wieku gwałtownie wzrósł import pojazdów, a funkcjonujące w kraju fabryki znalazły się w sytuacji silnej konkurencji, która wymusiła unowocześnienie produkcji, zwiększenie produktywności oraz poprawę jakości produkowanych pojazdów. Wymogło to na działających na tym rynku koncernach wzrost inwestycji związanych z modernizacją istniejących fabryk oraz produkowanych w nich modeli, a także budowę nowych fabryk, dostosowanych do najnowszych standardów i technologii produkcji. Najważniejszą rolę w budowie nowych fabryk odegrały koncerny, które zdecydowały się na inwestycje w Brazylii w drugiej połowie lat 90. XX wieku. Po skutecznym wprowadzeniu w 1994 roku Planu Real, dzięki któremu opanowano inflację i ożywiono popyt wewnętrzny, dynamicznie zaczęła wzrastać sprzedaż nowych samochodów. Nieobecne na tym rynku koncerny, biorąc pod uwagę demograficzny potencjał kraju, niski wskaźnik motoryzacji i optymistyczne prognozy rozwoju gospodarczego, dostrzegły w Brazylii bardzo ważny perspektywiczny rynek do „zagospodarowania”. Od czasu budowy przez koncern Honda w 1997 roku fabryki w mieście Sumare pojawiło się w tym kraju jeszcze osiem innych koncernów: Peugeot Citroen, Renault, Toyota, Mitsubishi, Nissan, Mercedes Benz, Hyundai i Mahindra (Laplane, Sarti, 1997; Laplane, Sarti, 2004; Rodríguez-Pose, Arbix, 2001; Wójtowicz, 2008; Wójtowicz, 2012).

Wkroczenie nowych producentów, połączone z inwestycjami firm już obecnych na rynku, wywołało duży boom inwestycyjny związany z rozbudową istniejących fabryk oraz powstawaniem nowych. W latach 1994-2012 łączna wielkość inwestycji w produkcję samochodów oraz części i podzespołów wyniosła 68 mld USD, a zainstalowane moce produkcyjne sięgnęły 4,5 mln pojazdów (Anuário da Indústria Automobilística Brasileira, 2013). Nowe inwestycje w dużej mierze starały się omijać stare centra przemysłu przetwórczego, aby uniknąć silnych związków zawodowych i wyższych kosztów związanych z nadmierną koncentracją działalności przemysłowej oraz wysokimi cenami ziemi potrzebnej pod nowe inwestycje, co było widoczne w Regionie Metropolitalnym São Paulo (Rodríguez-Pose, Tomaney, 1999), a szczególnie w jego południowo-wschodniej części - tzw. trójkącie ABC, obejmującym miasta: Santo Andre, São Bernardo do Campo i São Caetano do Sul, które do końca lat 90. XX wieku były głównym centrum produkcji samochodów (Rodríguez-Pose, Tomaney, Klink, 2001). W efekcie doprowadziło to do wyraźnych przesunięć w przestrzennym rozmieszczeniu przemysłu motoryzacyjnego w Brazylii. 
Celem artykułu jest określenie zmian w przestrzennym rozmieszczeniu poszczególnych działów przemysłu motoryzacyjnego w Brazylii przy wykorzystaniu danych dotyczących wielkości zatrudnienia. W analizie wykorzystano podział na 26 stanów oraz Dystrykt Federalny, a w celu precyzyjniejszego rozmieszczenia zatrudnienia w przemyśle motoryzacyjnym, pozwalającego na wskazanie tworzących się jego skupień, wykorzystano dane dla 609 municypiów liczących powyżej 50 tys. mieszkańców. Zakres czasowy badań obejmuje lata 1996-2011, dla których dostępne są dane statystyczne z Centralnego Spisu Przedsiębiorstw (Cadastro Central de Empresas - CEMPRE), zbierane przez Brazylijski Instytut Geografii i Statystyki (Instituto Brasileiro de Geografia e Estatística - IBGE).

\section{ZMIANY WIELKOŚCI ZATRUDNIENIA I KONCENTRACJI PRZEMYSŁU SAMOCHODOWEGO W BRAZYLII}

Sukces gospodarczy wprowadzonego w 1994 roku Planu Real oraz prowadzona w kolejnych latach skuteczna polityka państwa stymulująca rozwój sektora motoryzacyjnego i zachęcająca do napływu nowych inwestorów zagranicznych, przyczyniły się do żywiołowego rozwoju tej gałęzi przemysłu (Salerno, Arbix, 2010; Ibusuki i in., 2012). W latach 1996-2011 zatrudnienie wzrosło ponad dwuipółkrotnie, przekraczając poziom 0,5 mln. Największy przyrost zatrudnionych odnotowano w dziale grupującym zakłady produkujące części i akcesoria do pojazdów mechanicznych, gdzie wyniósł on 381,1\% (ryc. 1). Dział ten stał się najważniejszy pod względem koncentracji zatrudnienia w całym przemyśle motoryzacyjnym, grupując w 2011 roku aż 61,4\% ogółu zatrudnionych (tab. 1). Tak dynamiczny jego rozwój wskazuje na rosnące zakorzenienie brazylijskiego sektora motoryzacyjnego, związane z napływem do tego kraju coraz większej liczby firm kooperujących z producentami samochodów w celu zacieśniania współpracy i skrócenia łańcuchów dostaw (Humphrey, 2003; Salerno i in., 2009).

Warto również zauważyć, iż w badanym okresie dział produkcji części i akcesoriów do pojazdów mechanicznych odnotował najniższą wartość współczynnika redystrybucji, wynoszącą zaledwie 0,129 , co wskazuje na stosunkowo najmniejsze zmiany w przestrzennym rozmieszczeniu zatrudnienia $\mathrm{w}$ tym dziale $^{1}$. Na tej podstawie można wnioskować, że wskazany wcześniej największy przyrost zatrudnienia w dużej mierze miał miejsce w stanach, w których już wcześniej istniały zakłady zaliczane do tego przemysłu, nie powodując znaczących przesunięć zatrudnienia. Odmiennie prezentowała się natomiast sytuacja w dziale obejmującym produkcję samochodów osobowych i lekkich dostawczych. W przypadku tego

${ }^{1}$ Współczynnik redystrybucji (Wr) obliczono na podstawie wzoru:

$W_{r}=\frac{1}{200} \sum_{i=1}^{n}\left|p_{i}^{t_{0}}-p_{i}^{t_{1}}\right|$ gdzie:

$p_{i}$ - procentowy udział zatrudnionych w przemyśle $i$-tego stanu w stosunku do zatrudnienia w całej Brazylii $\mathrm{w} \mathrm{t}_{0} \mathrm{i}_{1}$ przekroju czasowym. Wartości współczynnika mogą się wahać od 0 do 1 , przy czym im wartości bliższe 1 , tym większe zmiany w rozmieszczeniu przestrzennym badanego przemysłu. 
działu wartości współczynnika przesunięć wskazują na największe zmiany w koncentracji zatrudnienia $(0,268)$, przy czym warto zaznaczyć, iż sama jego wielkość uległa stosunkowo niewielkiemu wzrostowi - zaledwie o $21,6 \%$ (tab. 1). Wynikało to z polityki koncernów samochodowych, które $\mathrm{w}$ ramach transformacji i restrukturyzacji produkcji decydowały się raczej na budowę zupełnie nowych zakładów, zlokalizowanych z dala od starych centrów przemysłowych, niż na modernizację istniejących fabryk, co często wiązało się z dużą redukcją zatrudnienia i silnymi oporami związków zawodowych (Laplane, Sarti, 1997; Rachid i in., 2002; Wójtowicz, 2008). Z drugiej strony, wraz z zainicjowanym w połowie lat 80. XX wieku procesem demokratyzacji, rosła rola lokalnych i regionalnych władz, które poprzez ulgi w podatkach oraz pomoc w przygotowaniu infrastruktury zaczęły coraz ostrzej rywalizować między sobą o przyciągnięcie któregoś z koncernów samochodowych, w nadziei, że wybudowanie fabryki produkującej pojazdy przyciągnie do danego stanu czy miasta także kooperantów i wpłynie na wzrost zatrudnienia (Rodríguez-Pose, Arbix, 2001; Cavalcante, Uderman, 2007; Lopes, 2007).
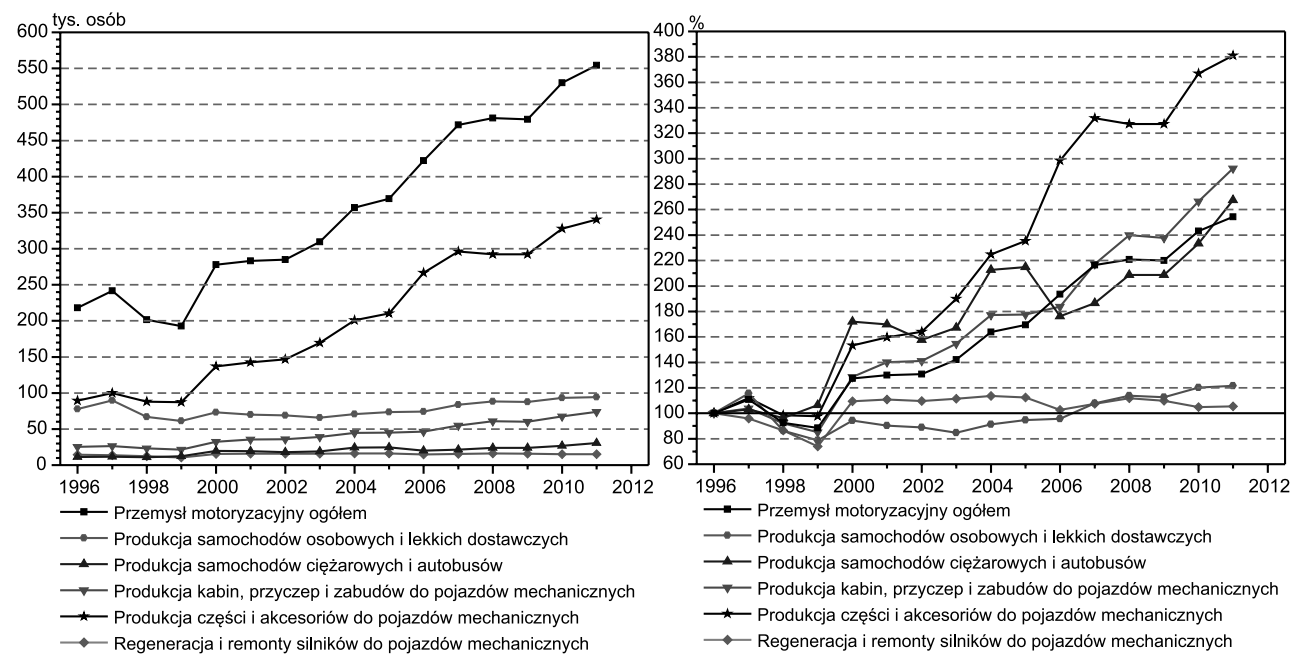

Ryc. 1. Zmiany wielkości i dynamiki zatrudnienia w przemyśle samochodowym Brazylii: 1996-2011

Źródło: opracowanie własne na podstawie danych Cadastro Central de Empresas (CEMPRE), 1996-2011, IBGE

Kolejnym działem przemysłu samochodowego, który wykazywał dynamiczny rozwój w badanym okresie, była produkcja kabin, przyczep i zabudów do pojazdów mechanicznych, w przypadku której odnotowano blisko trzykrotny wzrost zatrudnienia powiązany ze znaczącym jego przesunięciem pomiędzy stanami, o czym świadczy druga co do wielkości wartość współczynnika redystrybucji, wynosząca 0,195. Podobną tendencję zaobserwowano także w przypadku produkcji samochodów ciężarowych i autobusów, w której zatrudnienie w badanym okresie wzrosło o ponad $167 \%$, a współczynnik redystrybucji wyniósł 0,171 . Najniższą dynamiką zmian zatrudnienia cechował się natomiast dział zajmujący się regeneracją i remontami silników d o pojazdów mechanicznych, w przypadku którego odnotowano 
wzrost zaledwie o 5,5\%, przy jednocześnie stosunkowo wysokiej wartości współczynnika przesunięć, wskazującej na znaczne zmiany rozmieszczenia zatrudnienia w tym dziale pomiędzy stanami (tab. 1). Wykazuje on zarazem najniższy poziom koncentracji zarówno pod względem rozmieszczenia ludności, jak i zatrudnienia w przemyśle przetwórczym, co należy wiązać z faktem, iż należące do niego zakłady lokalizują się zgodnie z rozkładem ludności i ilości samochodów (tab. 2).

Tab. 1. Zmiana wielkości zatrudnienia oraz współczynnik redystrybucji w poszczególnych działach przemysłu samochodowego Brazylii w latach 1996-2011

\begin{tabular}{|c|c|c|c|c|}
\hline \multirow{2}{*}{ Przemysł } & \multicolumn{2}{|c|}{ Zatrudnienie w tys. osób } & \multirow{2}{*}{$\begin{array}{c}\text { Zmiana } \\
1996=100 \%\end{array}$} & \multirow{2}{*}{$\begin{array}{c}\text { Współczynnik } \\
\text { redystrybucji } \\
\text { Wr } \\
\end{array}$} \\
\hline & 1996 & 2011 & & \\
\hline przemysł samochodowy ogółem & 217,9 & 554,1 & 254,3 & 0,151 \\
\hline $\begin{array}{l}\text { produkcja samochodów } \\
\text { osobowych i lekkich dostawczych }\end{array}$ & 77,6 & 94,3 & 121,6 & 0,268 \\
\hline $\begin{array}{l}\text { produkcja samochodów } \\
\text { ciężarowych i autobusów }\end{array}$ & 11,4 & 30,5 & 267,4 & 0,171 \\
\hline $\begin{array}{l}\text { produkcja kabin, przyczep } \\
\text { i zabudów do pojazdów } \\
\text { mechanicznych }\end{array}$ & 25,3 & 73,9 & 292,3 & 0,195 \\
\hline $\begin{array}{l}\text { produkcja części i akcesoriów } \\
\text { do pojazdów mechanicznych }\end{array}$ & 89,3 & 340,3 & 381,1 & 0,129 \\
\hline $\begin{array}{l}\text { regeneracja i remont silników } \\
\text { do pojazdów mechanicznych }\end{array}$ & 14,3 & 15,1 & 105,5 & 0,169 \\
\hline
\end{tabular}

Źródło: opracowanie własne na podstawie danych Cadastro Central de Empresas (CEMPRE), 1996-2011, IBGE

Analiza zmian wartości współczynników lokalizacji pozwala wskazać kilka widocznych prawidłowości². Po pierwsze, wraz ze wzrostem wielkości zatrudnienia w poszczególnych działach przemysłu motoryzacyjnego doszło do znaczących spadków wartości współczynników lokalizacji względem trzech zmiennych odniesienia: powierzchni, liczby ludności i wielkości zatrudnienia w przemyśle przetwórczym. Jedynym wyjątkiem jest nieznaczny wzrost współczynnika lokalizacji produkcji kabin, przyczep i zabudów do pojazdów mechanicznych w stosunku do zatrudnienia w przemyśle przetwórczym. Kolejną ważną prawidłowością jest ciągle bardzo wysoka koncentracja przestrzenna zatrudnienia w poszczególnych działach przemysłu motoryzacyjnego, sięgająca, pomimo obserwowanych w badanym okresie

${ }^{2}$ Współczynnik lokalizacji (zwany też współczynnikiem koncentracji Florence’a) obliczono na podstawie wzoru:

$$
W_{k}=\frac{\sum_{i=1}^{n}\left|a_{i}-b_{i}\right|}{200} \text { gdzie: }
$$

$a_{i}-$ udział zatrudnionych w przemyśle w $i$-tym stanie w stosunku do całego kraju, natomiast $b_{i}-$ udział i-tego stanu w ogólnej powierzchni kraju, ogólnej liczbie ludności i ogólnej liczbie zatrudnionych w przemyśle przetwórczym. Wartości współczynnika mogą się wahać od 0 do 1 , przy czym im wartości bliższe 0 , tym większe rozproszenie badanego przemysłu (Czapliński i in., 2013, s.116-118). 
tendencji spadkowych, aż 0,837 w przypadku produkcji samochodów ciężarowych i autobusów. Warto zwrócić uwagę, iż jest to dział cechujący się w 2011 roku najwyższymi wartościami współczynników lokalizacji, co wskazuje, że w jego przypadku proces dyspersji zatrudnienia przebiegał zdecydowanie najsłabiej. Jednocześnie trzeba przypomnieć, iż należał on do jednych z najszybciej zwiększających liczbę zatrudnionych, co przemawia za stwierdzeniem, że rozbudowywał się głównie w stanach, w których już był wcześniej obecny (tab. 2).

Zdecydowanie niższe wartości odnotowano w przypadku koncentracji demograficznej, co potwierdza tendencję do skupiania się przemysłu motoryzacyjnego w najludniejszych stanach, które są zarazem głównymi rynkami zbytu. Stany te cechowały się także wysokim poziomem rozwoju gospodarczego, najdłuższymi tradycjami rozwoju przemysłu i relatywnie najlepszą w kraju infrastrukturą drogową. Natomiast najniższe wartości współczynnika lokalizacji odnotowano względem ogólnej struktury zatrudnienia w przemyśle przetwórczym, co wskazuje na lokalizację przemysłu motoryzacyjnego w stanach mających najlepiej rozwiniętą działalność przemysłową, która stanowiła zaplecze kooperacyjne dla przemysłu motoryzacyjnego, a z drugiej strony w stanach, które dysponowały wykwalifikowaną siłą roboczą, przygotowaną do pracy w tego typu zakładach. Obserwowane spadki wartości współczynników lokalizacji poszczególnych działów przemysłu motoryzacyjnego w stosunku do ogólnego zatrudnienia w przemyśle przetwórczym wskazują natomiast na jego postępującą dyspersję i upodabnianie się do ogólnej struktury przestrzennej przemysłu w Brazylii (tab. 2).

Tab. 2. Zmiany wartości wskaźnika stopnia koncentracji przemysłu samochodowego w Brazylii w latach 1996-2011

\begin{tabular}{|l|c|c|c|c|c|c|}
\hline \multirow{2}{*}{\multicolumn{1}{|c|}{ Przemysł }} & \multicolumn{5}{c|}{ Współczynniki lokalizacji $\left(\mathrm{W}_{\mathrm{k}}\right)$} \\
\cline { 2 - 7 } & \multicolumn{2}{|c|}{$\begin{array}{c}\text { względem } \\
\text { powierzchni }\end{array}$} & \multicolumn{2}{c|}{$\begin{array}{c}\text { względem } \\
\text { ludności }\end{array}$} & \multicolumn{2}{c|}{$\begin{array}{c}\text { względem zatrudnienia } \\
\text { w przemyśle } \\
\text { przetwórczym }\end{array}$} \\
\cline { 2 - 8 } & 1996 & 2011 & 1996 & 2011 & 1996 & 2011 \\
\hline przemysł samochodowy ogółem & 0,802 & 0,770 & 0,511 & 0,446 & 0,307 & 0,237 \\
\hline $\begin{array}{l}\text { produkcja samochodów osobowych } \\
\text { i lekkich dostawczych }\end{array}$ & 0,897 & 0,759 & 0,672 & 0,475 & 0,485 & 0,322 \\
\hline $\begin{array}{l}\text { produkcja samochodów ciężarowych } \\
\text { i autobusów }\end{array}$ & 0,884 & 0,837 & 0,693 & 0,564 & 0,507 & 0,394 \\
\hline $\begin{array}{l}\text { produkcja kabin, przyczep i zabudów } \\
\text { do pojazdów mechanicznych }\end{array}$ & 0,783 & 0,737 & 0,492 & 0,371 & 0,245 & 0,256 \\
\hline $\begin{array}{l}\text { produkcja części i akcesoriów } \\
\text { do pojazdów mechanicznych }\end{array}$ & 0,820 & 0,794 & 0,531 & 0,483 & 0,316 & 0,282 \\
\hline $\begin{array}{l}\text { regeneracja i remont silników } \\
\text { do pojazdów mechanicznych }\end{array}$ & 0,670 & 0,584 & 0,279 & 0,204 & 0,199 & 0,177 \\
\hline
\end{tabular}

Źródło: opracowanie własne na podstawie danych Cadastro Central de Empresas (CEMPRE), 1996-2011, IBGE

Największe spadki wartości współczynników lokalizacji odnotowano w przypadku produkcji samochodów osobowych i lekkich dostawczych, co związane jest ze wskazywanymi już wcześniej inwestycjami w nowe fabryki, budowane poza dawnymi centrami 
przemysłowymi, bliżej nowych rynków zbytu, w stanach i regionach, w których do tej pory nie sytuowano tego typu zakładów. Najbardziej znamiennymi przykładami tego typu inwestycji są fabryka koncernu Ford wybudowana w Camaçari, nieopodal miasta Salwador - stolicy stanu Bahía (Cavalcante, Uderman, 2007) lub duży kompleks przemysłowy koncernów Renault i Nissan, zlokalizowany w mieście São José dos Pinhais sąsiadującym z Kurytybą - stolicą stanu Parana (Lopes, 2007). Najniższy poziom koncentracji odnotowano natomiast w przypadku działu zajmującego się regeneracją i remontami silników, który - jak wspomniano powyżej - wykazywał najmniejszy wzrost zatrudnienia. W badanym okresie cechował się on dalszym spadkiem wartości współczynników koncentracji, co świadczy o jego postępującej dyspersji przestrzennej (tab. 2).

\section{ZMIANY REGIONALNEJ STRUKTURY PRZEMYSŁU SAMOCHODOWEGO}

W 1996 roku blisko 218 tys. osób zatrudnionych w przemyśle motoryzacyjnym Brazylii wykazywało bardzo silny poziom koncentracji przestrzennej $(0,802)$, skupiając się głównie w dwóch najludniejszych stanach: São Paulo (64,3\% ogółu zatrudnionych) i Minas Gerais $(17,4 \%)$. Poza wspomnianymi wiodącymi stanami, zakłady zaliczane do tego sektora funkcjonowały na mniejszą skalę w stanach: Rio Grande do Sul $(8,0 \%)$, Santa Catarina $(3,0 \%)$, Parana $(2,5 \%)$ i Rio de Janeiro (1,7\%). Natomiast udział pozostałych stanów był minimalny i ograniczony głównie do zatrudnienia w dziale regeneracji i remontów silników do pojazdów mechanicznych (ryc. 2).

Do 2011 roku zatrudnienie w tym sektorze wzrosło do ponad 554 tys. osób przy jednoczesnym zmniejszeniu poziomu koncentracji przestrzennej do 0,770 , co wskazuje na istotne przesunięcia w jego regionalnej dystrybucji. Stanami najbardziej tracącymi na znaczeniu w krajowej strukturze zatrudnienia w sektorze motoryzacyjnym były: São Paulo i Minas Gerais, w których obniżył się on odpowiednio do 52,0\% i 15,3\%. Warto jednak zaznaczyć, iż spadki te dokonały się pomimo wzrostu zatrudnienia w liczbach bezwzględnych, wynoszącego w São Paulo 148,2 tys., a w Minas Gerais 47,0 tys. (ryc. 2). Najbardziej zyskały na znaczeniu stany Regionu Południowego, w których udział zatrudnienia w sektorze motoryzacyjnym zwiększył się do 10,4\% w Rio Grande do Sul, 8,9\% w Paranie i 4,3\% w Santa Catarina. Łącznie w badanym okresie udział tych stanów w strukturze przestrzennej zwiększył się z 13,5\% do 23,6\%, natomiast zatrudnienie w liczbach bezwzględnych wzrosło z 29,4 do 130,7 tys. osób. Spośród stanów Południa na szczególną uwagę zasługuje Parana, w której odnotowano blisko dziewięciokrotny przyrost zatrudnienia, z 5,5 do 49,4 tys. osób, co wiązało się z napływem nowych inwestycji koncernów Renault, Nissan i Volkswagen (Audi) oraz firm z nimi współpracujących. Tak dynamiczny wzrost zatrudnienia w stanach południowych wiązał się z postępującym procesem integracji w ramach Mercosur. Dla koncernów międzynarodowych inwestycje w tych stanach miały strategiczne znaczenie w długofalowej strategii tworzenia regionalnych łańcuchów dostaw, łączących fabryki działające w Argentynie i Brazylii (Santos, Pinhão, 1999; Lopes, 2007; Wójtowicz, 2009). 


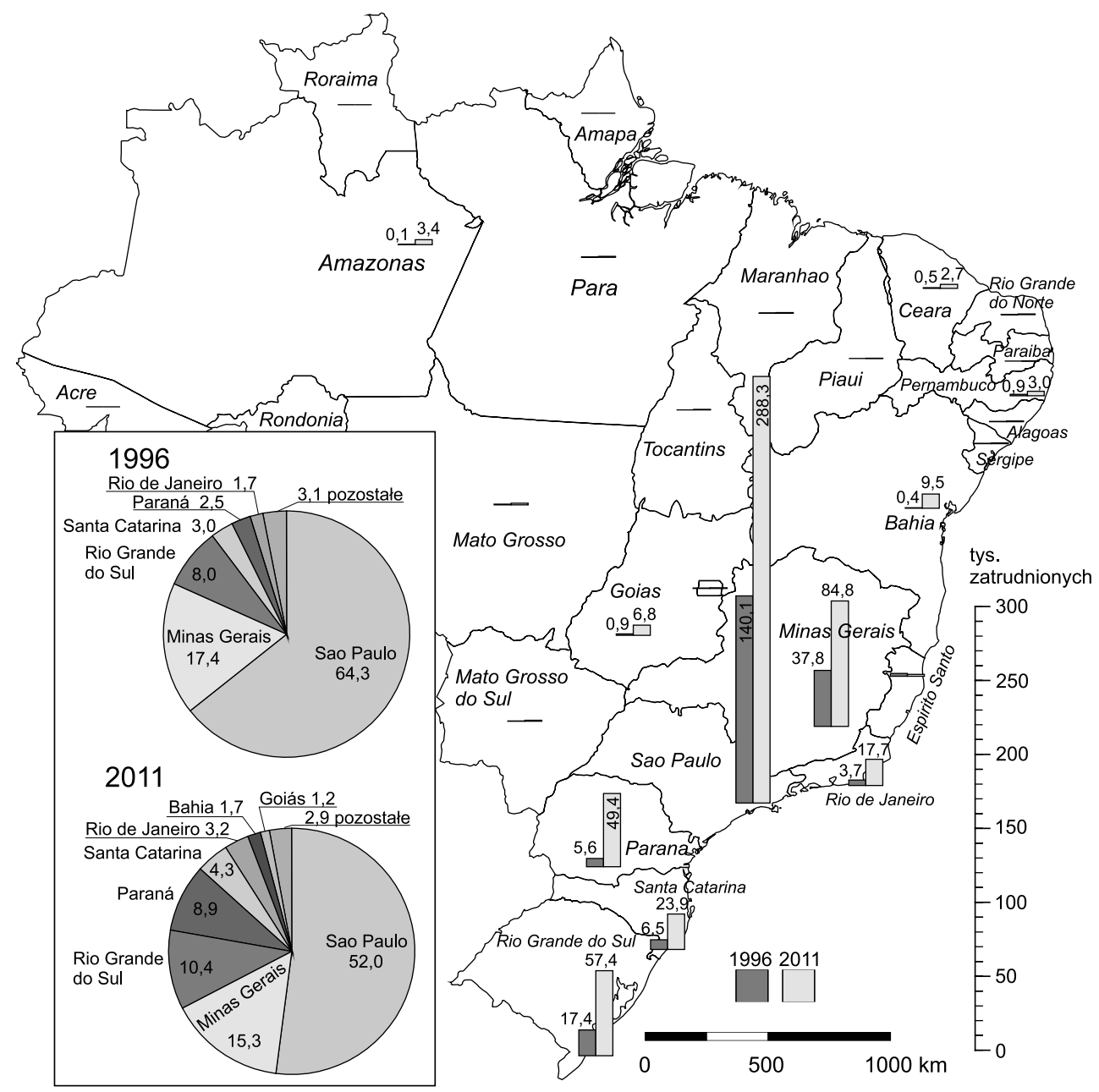

Ryc. 2. Zmiany w regionalnej dystrybucji zatrudnienia w przemyśle samochodowym Brazylii w latach 1996-2011

Źródło: opracowanie własne na podstawie danych Cadastro Central de Empresas (CEMPRE), 1996-2011, IBGE

Warto również zwrócić uwagę, że - oprócz wspomnianych powyżej stanów z Regionu Południowego - wzrosło także znaczenie trzech stanów z centralnej części kraju, a ich udział w strukturze zatrudnienia w sektorze motoryzacyjnym wyniósł w 2011 roku odpowiednio: Rio de Janeiro (3,2\%), Bahía (1,7\%) i Goiás (1,2\%) (ryc. 2). Wynikało to również z faktu, iż zostały w nich zlokalizowane nowe inwestycje związane z produkcją samochodów: Rio de Janeiro (Peugeot Citroen, MAN), Bahía (Ford), Goiás (Mitsubishi, CAOA), a wraz z nimi pojawiły się też kooperujące firmy (Santos, Pinhão, 1999; Wójtowicz, 2008).

Zmiany wartości ilorazu lokalizacji przemysłu motoryzacyjnego $\mathrm{w}$ stosunku do ogólnego zatrudnienia w przemyśle przetwórczym wskazują, iż w latach 1996-2011 do grona 
dwóch stanów (São Paulo i Minas Gerais), cechujących się wyraźną nadreprezentacją zatrudnienia w tym sektorze na tle całego przemysłu przetwórczego, dołączyły kolejne dwa (Rio Grande do Sul i Parana). Warto również zwrócić uwagę, że w wyniku przemian struktury przestrzennej tego sektora także w kilku innych stanach odnotowano zwiększenie się jego znaczenia, o czym świadczy wzrost wartości ilorazu lokalizacji w badanym okresie. Do tej grupy można zaliczyć stany: Santa Catarina, Rio de Janeiro, Goiás, Bahía i Amazonas. W przypadku dwóch ostatnich zaobserwowane zmiany przedmiotowego wskaźnika oznaczają, iż na początku badanego okresu przemysł ten był w nich praktycznie nieobecny, a ich wzrost w 2011 roku jest wynikiem nowych inwestycji, wyraźnie zmieniających strukturę przemysłu przetwórczego w ich obrębie (ryc. 3).

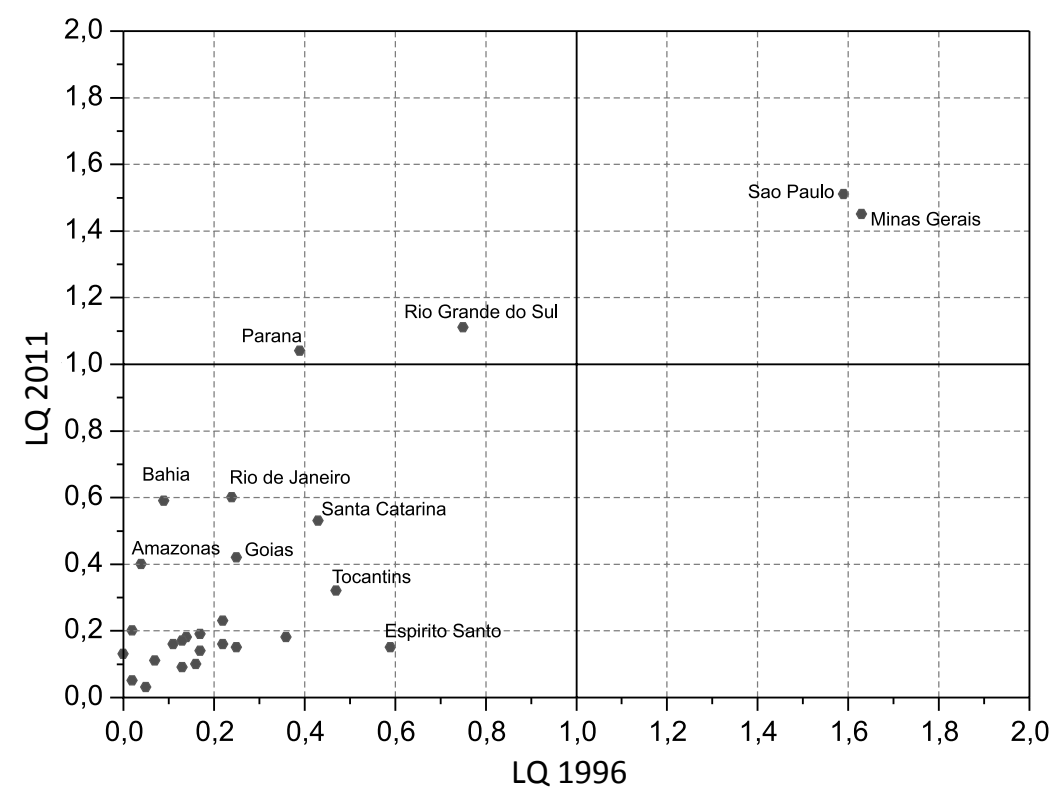

Ryc. 3. Zmiany ilorazu lokalizacji (LQ) zatrudnionych w przemyśle samochodowym do zatrudnionych w przemyśle przetwórczym ogółem

Źródło: opracowanie własne na podstawie danych Cadastro Central de Empresas (CEMPRE), 1996-2011, IBGE

Odmienną sytuację zaobserwowano w przypadku stanów: Espírito Santo, Tocantins i Dystryktu Federalnego, w których w badanym okresie wartości ilorazu lokalizacji spadły, wskazując na spadek znaczenia sektora motoryzacyjnego w strukturze przemysłu przetwórczego. Wiązać to należy $\mathrm{z}$ faktem, iż w badanym okresie stany te nie przyciągnęły żadnych znaczących inwestycji związanych z tym sektorem, a nawet w przypadku Espírito Santo doszło do znacznej redukcji zatrudnienia z 1,9 do 1,3 tys. osób, co znalazło odzwierciedlenie w największym spadku wartości ilorazu lokalizacji, z 0,59 do 0,15 (ryc. 3). 


\section{ZMIANY REGIONALNEJ STRUKTURY PRODUKCJI SAMOCHODÓW}

Na podstawie analizowanego wcześniej współczynnika redystrybucji stwierdzono, iż najwyższe wartości notował on w dziale związanym z produkcją samochodów osobowych i lekkich dostawczych, a stosunkowo wysokie także w dziale związanym z produkcją samochodów ciężarowych i autobusów (tab. 1). Również w 1996 roku te dwa działy cechowały się najwyższymi wartościami wskaźnika koncentracji przestrzennej, co wskazuje na to, iż już w początkowym momencie badań były one bardzo silnie skoncentrowane przestrzennie (tab. 2). Natomiast w badanym okresie przeszły one najgłębsze przemiany pod względem rozmieszczenia regionalnego. Biorąc pod uwagę fakt, iż za zmianami lokalizacji fabryk produkujących pojazdy często podążają także ich poddostawcy, analiza zmian zatrudnienia w działach związanych z produkcją samochodów pozwoli lepiej zrozumieć dokonujące się w Brazylii przesunięcia przestrzenne w obrębie całego sektora motoryzacyjnego.

W 1996 roku aż 99,1\% zatrudnienia w fabrykach produkujących pojazdy samochodowe skupiało się w dwóch stanach, przy czym zdecydowanie dominował stan São Paulo, koncentrujący 3/4 ogółu zatrudnionych. Natomiast udział Minas Gerais wynosił 24,1\%. W ciągu analizowanych 15 lat udział tych stanów zmniejszył się do 73,9\% ogółu zatrudnionych przy produkcji pojazdów. Warto zwrócić uwagę, że w przypadku São Paulo spadek ten nastąpił pomimo wzrostu zatrudnienia o 13,4\%. Głęboki spadek udziału odnotowany w Minas Gerais wiązał się także ze znacznym zmniejszeniem zatrudnienia w tym stanie, o 29,9\% (ryc. 4). Przy czym w obu stanach wiązało się to z procesami modernizacji istniejących fabryk i budowy nowych. O ile w przypadku São Paulo restrukturyzacji i modernizacji starych zakładów towarzyszyło jednocześnie powstawanie nowych fabryk, budowanych zarówno przez działające już na brazylijskim rynku koncerny, jak i firmy dopiero na niego wchodzące (np.: Toyota, Honda, Hyundai), o tyle w przypadku Minas Gerais napływ nowych inwestycji związanych z produkcją samochodów był niewielki (jedynie Mercedes Benz), a restrukturyzacja starych fabryk Fiata $\mathrm{w}$ Betim wiązała się ze sporymi ograniczeniami zatrudnienia (Perobelli i in., 2007; Quadros, Consoni, 2009).

Do 2011 roku pojawiło się kilka nowych stanów, w których rozwinęła się produkcja samochodów. Na szczególną uwagę zasługuje Parana, w której zatrudnienie wzrosło w tym okresie z niecałych 100 osób do blisko 12,6 tys., głównie dzięki wspomnianym wcześniej inwestycjom Renault i Volkswagena, co sprawiło, iż na końcu badanego okresu koncentrowało się w tym stanie już 10,4\% ogółu zatrudnionych przy produkcji pojazdów w Brazylii. Podobne przemiany zaszły w przypadku kolejnych czterech stanów (Rio de Janeiro, Rio Grande do Sul, Bahía i Goiás), w których dzięki budowie nowych fabryk gwałtownie wzrosło zatrudnienie związane z produkcją samochodów (ryc. 4). 


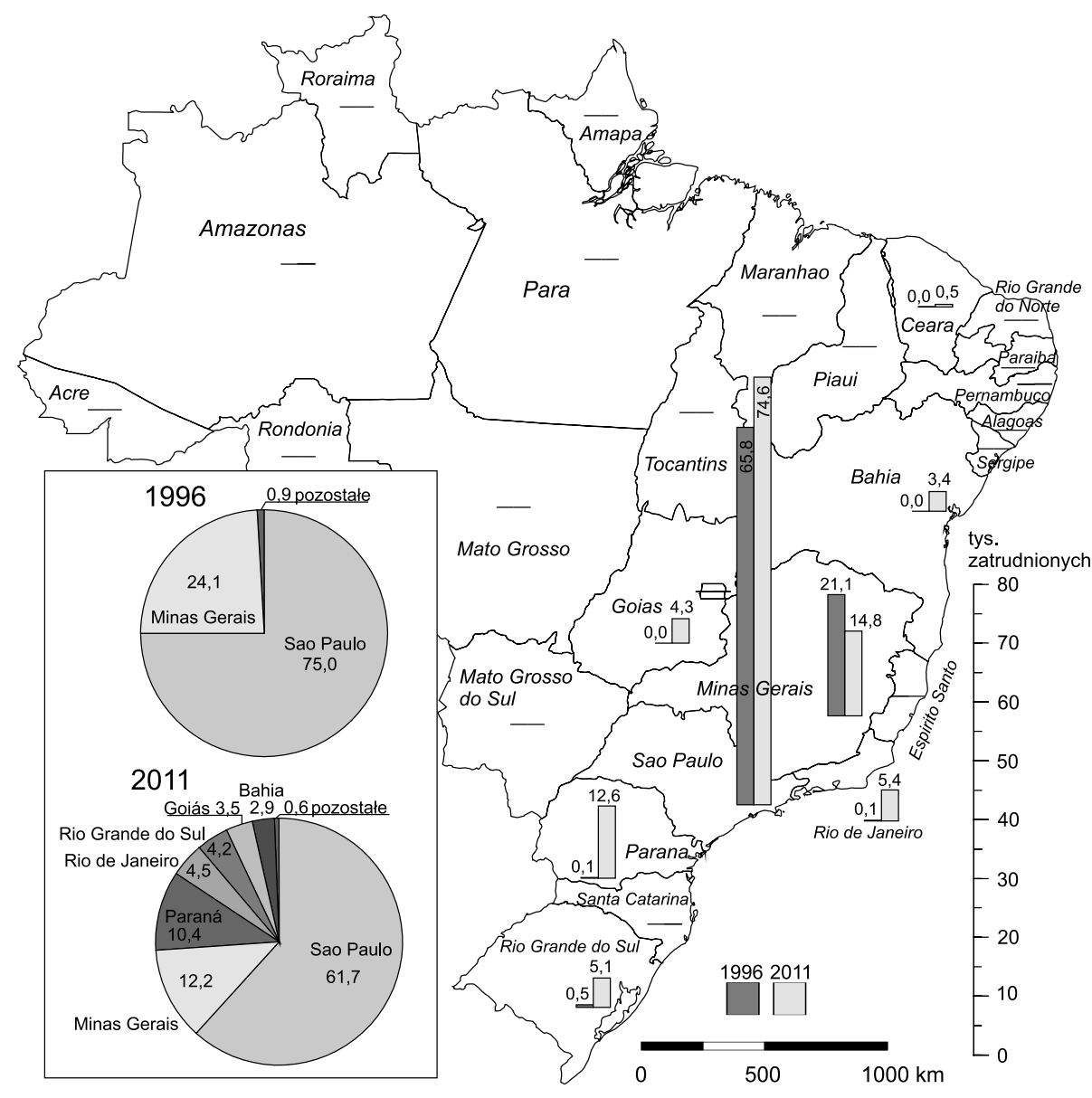

Ryc. 4. Zmiany w regionalnej dystrybucji zatrudnienia w sektorze produkcji pojazdów samochodowych w latach 1996-2011

Źródło: opracowanie własne na podstawie danych Cadastro Central de Empresas (CEMPRE), 1996-2011, IBGE

Zmiany wartości ilorazu lokalizacji pozwalają stwierdzić, iż w 1996 roku jedynie w São Paulo i Minas Gerais zatrudnienie w produkcji samochodów wykazywało wyraźną koncentrację na tle całego przemysłu przetwórczego, jednakże do 2011 roku w obu stanach odnotowano spadki wartości przedmiotowego wskaźnika, szczególnie duże w przypadku Minas Gerais. Pojawiły się natomiast dwa kolejne stany (Parana i Goiás), w których odnotowano wzrost koncentracji zatrudnienia w tym sektorze powyżej średniej krajowej, związany ze wspomnianymi wcześniej nowymi inwestycjami. Znaczące wzrosty ilorazu lokalizacji zaobserwowano także w przypadku stanów: Bahía, Rio de Janeiro i Rio Grande do Sul, w których na początku badanego okresu zatrudnienie w tym sektorze nie występowało lub było bardzo niewielkie (ryc. 5). 


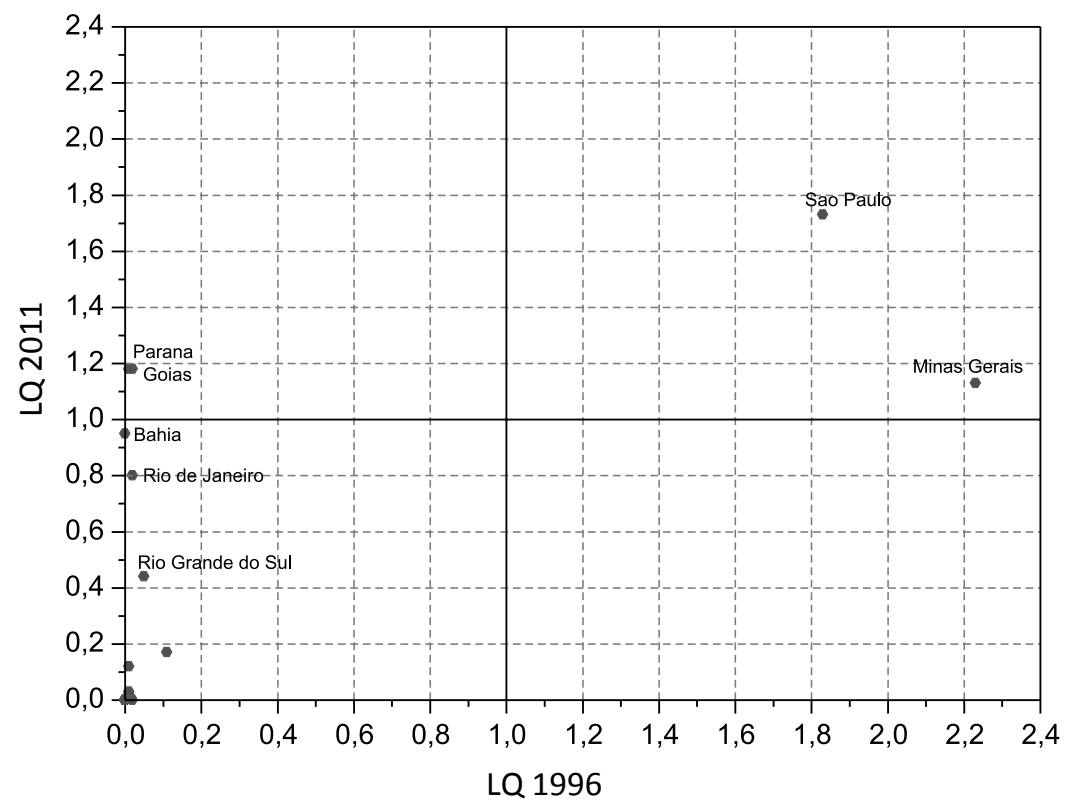

Ryc. 5. Zmiany ilorazu lokalizacji (LQ) zatrudnionych w produkcji pojazdów samochodowych do zatrudnionych w przemyśle przetwórczym ogółem

Źródło: opracowanie własne na podstawie danych Cadastro Central de Empresas (CEMPRE), 1996-2011, IBGE

\section{ZMIANY REGIONALNEJ STRUKTURY PRODUKCJI CZĘŚCI}

\section{AKCESORIÓW SAMOCHODOWYCH}

Najbardziej dynamicznie rozwijającym się działem przemysłu motoryzacyjnego Brazylii jest produkcja części i akcesoriów do pojazdów mechanicznych, w którym zatrudnienie wzrosło w badanym okresie blisko czterokrotnie. Jednocześnie dział ten odnotował najniższą wartość współczynnika redystrybucji, co wskazywałoby na stosunkowo niewielkie przesunięcia przestrzenne w strukturze zatrudnienia w tym przemyśle. Podobnie jak w przypadku wcześniejszych działów główną rolę odgrywają stany São Paulo i Minas Gerais, które koncentrowały w 1996 roku 82,5\% ogółu zatrudnienia. Udział ten jednak znacząco się obniżył do 73,2\% w 2011 roku, choć zatrudnienie w liczbach bezwzględnych wzrosło w tych stanach o 175,4 tys. osób, co stanowiło aż $69,9 \%$ całego przyrostu zatrudnienia w tym sektorze, wynoszącego w badanym okresie ok. 251 tys. osób (ryc. 6).

Znaczący rozwój przemysłu części samochodowych odnotowano w przypadku stanów Regionu Południowego: Parany, Santa Catarina i Rio Grande do Sul. Zatrudnienie w tym sektorze wzrosło w nich w badanym okresie z 12,3 tys. do 72,7 tys. osób, co sprawiło, że ich udział w skali kraju wzrósł z 13,7\% do 21,4\% (ryc. 6). Tak dynamiczny rozwój tego sektora wynikał nie tylko ze wskazanych wcześniej nowych inwestycji w produkcję samochodów, 
jakie napłynęły do tych stanów, ale także w znacznym stopniu z tworzenia się sieci powiązań z fabrykami działającymi w Argentynie, czemu sprzyjało położenie tych stanów i dobrze przygotowana siła robocza. Podobnego efektu dynamicznego wzrostu zatrudnienia w sektorze części samochodowych nie obserwujemy w przypadku kolejnych trzech stanów, w których w badanym okresie powstały nowe zakłady produkujące samochodowy (Bahía, Rio de Janeiro i Goiás). Faktem jest, iż zatrudnienie w sektorze produkcji części samochodowych zwiększyło się w nich z 2,2 tys. do 12,2 tys. osób, jednakże w porównaniu z prezentowanymi wcześniej stanami Regionu Południowego wzrost ten był relatywnie niewielki (ryc. 6). Przemawia to za stwierdzeniem, iż przesunięcia w produkcji samochodów nie są jedynym czynnikiem zmian w rozmieszczeniu przemysłu części samochodowych, ale że zmiany te zależą również od tworzących się w obrębie Mercosur regionalnych łańcuchów dostaw oraz zaplecza przemysłowego i kwalifikacji siły roboczej w poszczególnych stanach.

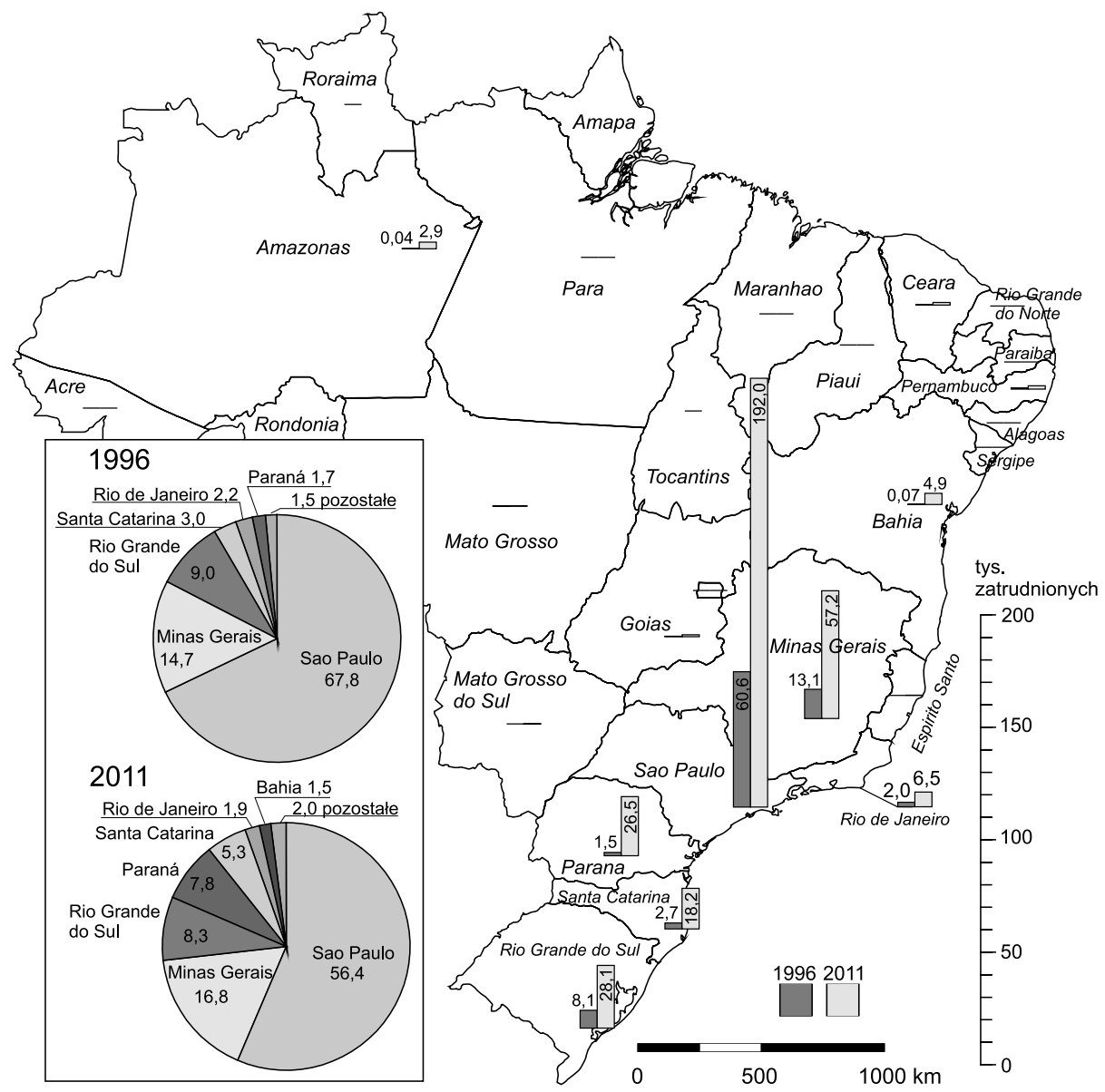

Ryc. 6. Zmiany regionalnej dystrybucji zatrudnienia w sektorze produkcji części i akcesoriów samochodowych w latach 1996-2011

Źródło: opracowanie własne na podstawie danych Cadastro Central de Empresas (CEMPRE), 1996-2011, IBGE 
Wzrost zatrudnienia w przemyśle części samochodowych, jaki zanotowały dwa wiodące stany: São Paulo i Minas Gerais, pozwolił im utrzymać - a w przypadku drugiego nawet zwiększyć - wartość ilorazu lokalizacji. Świadczy to o utrzymaniu przez nie wiodącej pozycji w koncentracji zatrudnienia w tym dziale przemysłu w skali kraju. Pomimo obserwowanego przyrostu zatrudnienia w innych stanach, w żadnym z nich nie okazał się on na tyle wysoki, aby iloraz lokalizacji przekroczył wartość 1, świadczącą o równomiernym rozmieszczeniu tego działu w porównaniu do całego przemysłu przetwórczego. Najbliżej osiągnięcia tego poziomu w 2011 roku były Parana $(0,91)$ i Rio Grande do Sul $(0,89)$, natomiast już w przypadku Santa Catarina czy Bahía wartości przedmiotowego wskaźnika wyniosły odpowiednio: 0,66 i 0,50 (ryc. 7).

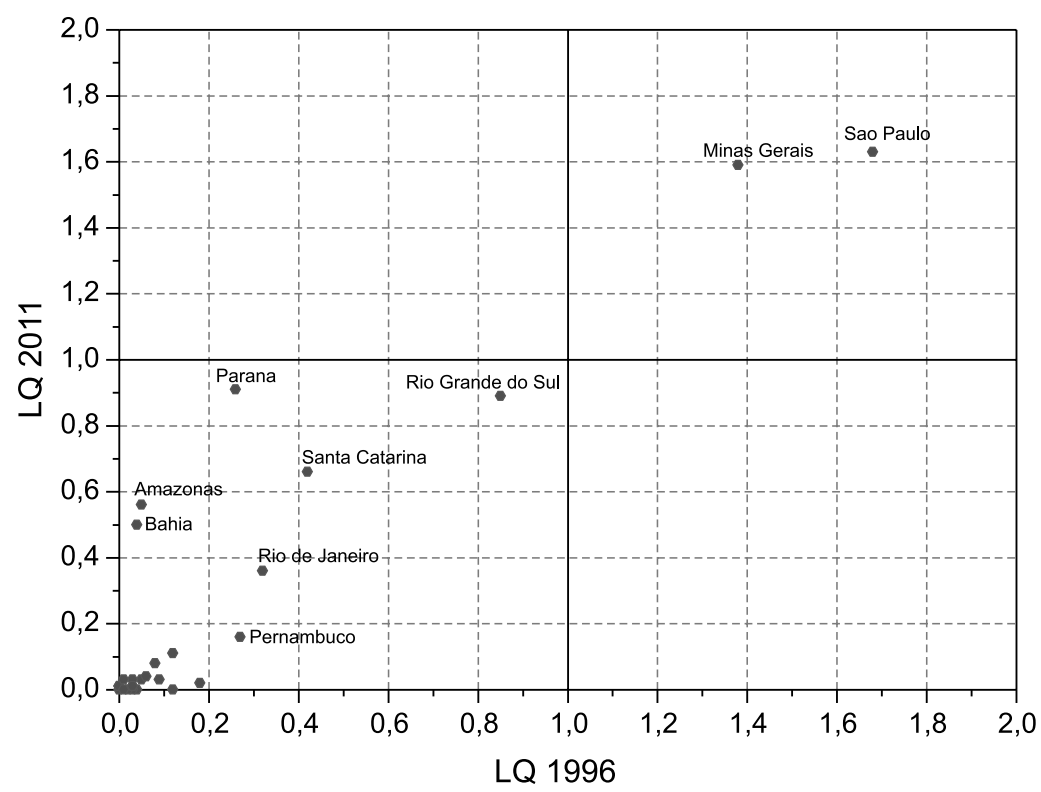

Ryc. 7. Zmiany ilorazu lokalizacji (LQ) zatrudnionych w produkcji części i akcesoriów samochodowych do zatrudnionych w przemyśle przetwórczym ogółem

Źródło: opracowanie własne na podstawie danych Cadastro Central de Empresas (CEMPRE), 1996-2011, IBGE

W grupie stanów notujących dynamiczny wzrost ilorazu lokalizacji na szczególną uwagę zasługuje Amazonas, w którym zwiększył się on z 0,05 do 0,56. Było to związane z nowymi inwestycjami, które pojawiły się w utworzonej w Manaus wolnej strefie ekonomicznej (Zona Franca de Manaus - ZFM). Zainwestowały w niej głównie firmy produkujące i montujące części samochodowe, ale w 2007 roku otwarto tu również montownię samochodów indyjskiego koncernu Mahindra przy współpracy z brazylijską firmą Bramont. Obecnie montowane są w niej samochody terenowe oraz lekkie dostawcze (ryc. 7). 


\section{REGIONALNE SKUPIENIA PRZEMYSŁU SAMOCHODOWEGO W BRAZYLII}

Przeprowadzone badania wskazują, że w analizowanym okresie zaszły wyraźne zmiany w regionalnej strukturze rozmieszczenia przemysłu samochodowego Brazylii. Ich skala była zróżnicowana w zależności od analizowanych działów, jednakże generalnie można stwierdzić, iż dokonały się istotne przesunięcia $\mathrm{w}$ rozmieszczeniu zatrudnienia pomiędzy stanami, wskazujące na postępującą dyspersję. Biorąc pod uwagę dostępne dane o wielkości zatrudnienia w przemyśle samochodowym dla 609 municypiów liczących powyżej 50 tys. mieszkańców, można wskazać pięć głównych skupień tego przemysłu w Brazylii. Pierwsze (1 na ryc. 8), a zarazem najmniejsze i najmłodsze z nich, zlokalizowane jest w stanie Bahía, w regionie metropolitalnym miasta Salwador. W 2011 roku w przemyśle samochodowym zatrudnionych było tu ponad 8,6 tys. osób. Największą rolę odgrywało miasto Camaçari, w którym w 2001 roku powstały duże zakłady Forda. Obecnie sektor motoryzacyjny zatrudnia $\mathrm{w}$ nim ponad 6 tys. osób. Ważną rolę w tym skupieniu odgrywają także municypia: Feria de Santana (1,5 tys. zatrudnionych), Simões Filho (0,8 tys. zatrudnionych) a także Dias d'Ávila, Salvador i Lauro Freitas (ryc. 8).

Kolejne skupienie tego przemysłu (2 na ryc. 8), a zarazem drugie co do wielkości w skali kraju, znajduje się w południowej części stanu Minas Gerais. Jego powstanie wiąże się z otwarciem w 1976 roku fabryki Fiata w mieście Betim, sąsiadującym ze stolicą stanu - Belo Horizonte. Obecnie najważniejsze ośrodki w tym skupieniu to municypia: Betim (27,6 tys. zatrudnionych), Contagem (6,9 tys.), Sete Lagoas (5,6 tys.), Belo Horizonte (4,4 tys.), Pará de Minas (1,1 tys.) (ryc. 8$)$.

Trzecie skupienie (3 na ryc. 8), również tworzące się głównie dzięki inwestycjom dokonanym w ostatnich latach, powstało w stanie Rio de Janeiro. Najważniejszymi jego centrami są dwa miasta leżące w zachodniej części stanu, tuż przy granicy z São Paulo. Pierwsze z nich - Resende, w którym w 1996 roku swoją nową fabrykę samochodów ciężarowych i autobusów wybudował Volkswagen (obecnie firma nazywa się MAN Latin America), zatrudnia ok. 2,9 tys. osób. Drugie to sąsiadujące z nim Porto Real, w którym w 2001 roku powstał duży kompleks przemysłowy Peugeot Citroen, obejmujący nie tylko fabrykę samochodów, ale także silników, który zatrudnia ok. 4 tys. pracowników. Kolejne ważne ośrodki związane z przemysłem samochodowym znajdują się w Regionie Metropolitalnym Rio de Janeiro i obejmują: Duque de Caxias (3,1 tys. zatrudnionych), Rio de Janeiro (1,8 tys.), Nova Iguaçu (1 tys.) (ryc. 8).

Największe, a zarazem najstarsze skupienie przemysłu motoryzacyjnego wytworzyło się w północno-wschodniej części stanu São Paulo, w sąsiedztwie jego stolicy (4 na ryc. 8). Najważniejszymi municypiami wchodzącymi w jego skład są: São Bernadro do Campo (49,6 tys. zatrudnionych), São Paulo (33,8 tys.), Guarulhos (15,5 tys.), São Caetano do Sul (12,6 tys.), Taubaté (12,0 tys.), São José dos Campos (10,6 tys.), Campinas (10,6 tys.) i Diadema (8,8 tys.). W skupieniu tym znajdują się również nowe municypia, w których zakłady produkujące samochody pojawiły się w ostatnich kilkunastu latach, a wielkość zatrudnienia nie jest aż tak wielka, ze względu na nowoczesne linie montażowe. Należą do nich 
np. Indaiatuba (6,1 tys.) i Sorocaba (6,2 tys.) z nowymi fabrykami koncernu Toyota, Sumare (4,7 tys.) z fabryką Hondy czy Piracicaba (1,9 tys.) z nową fabryką Hyundaia (ryc. 8).

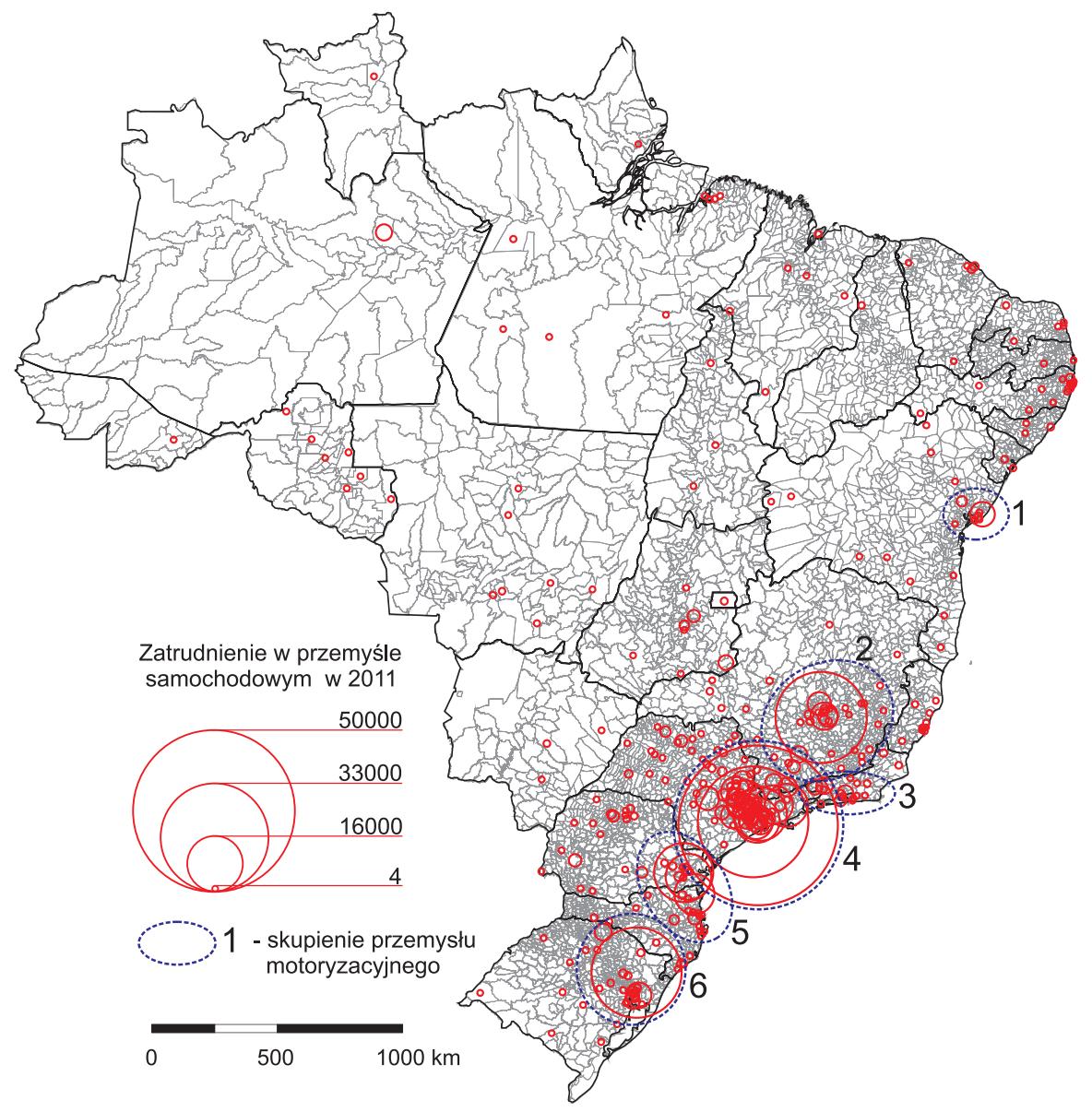

Ryc. 8. Regionalne zróżnicowanie zatrudnienia w przemyśle samochodowym wg głównych municypiów Brazylii w 2011 roku

Źródło: opracowanie własne na podstawie danych Cadastro Central de Empresas (CEMPRE), 1996-2011, IBGE

Piąte skupienie powstało we wschodniej części stanów Parana i Santa Catarina i choć ma długie tradycje, ponieważ pierwsze inwestycje Volvo pojawiły się w Kurytybie już w 1979 roku, jednak największy rozwój przeżywa w ostatnich kilkunastu latach. Najważniejsze ośrodki w tym skupieniu to: Kurytyba (17,2 tys. zatrudnionych), sąsiadujące z nią São José dos Pinhais (12,9 tys.) oraz leżące w północno-wschodniej części Santa Catarina miasto Joinville (11,1 tys.). Ponadto w tym skupieniu liczą się jeszcze municypia: Araucária (1,2 tys.), Irati (1,6 tys.), Brusque (2,1 tys.) (5 na ryc. 8$)$. 
Ostatnie ważne skupienie, dynamicznie rozwijające się w ostatnich dekadach, leży w północno-wschodniej części stanu Rio Grande do Sul (6 na ryc. 8). Jego centrum stanowi municypium Caxias do Sul (27,2 tys. zatrudnionych), w którym zlokalizowana jest fabryka firmy Agrale, produkującej samochody dostawcze, ciężarowe i autobusy oraz silniki do nich. Jest to jedyna duża firma samochodowa $\mathrm{z}$ kapitałem brazylijskim działająca $\mathrm{w}$ tym kraju. Poza nią funkcjonuje tu jeszcze fabryka firmy International, również wyspecjalizowana w produkcji samochodów ciężarowych i autobusów. Drugim ważnym ośrodkiem w tym skupieniu jest leżące na południu miasto Gravataí, w którym od 2000 roku działa fabryka General Motors, a zatrudnienie w przemyśle motoryzacyjnym wyniosło w 2011 roku blisko 6,4 tys. osób. Drugorzędnymi ośrodkami w tym skupieniu są natomiast leżące na północy: Erechim (3,6 tys.), stolica stanu Porto Alegre (3,1 tys.) oraz znajdujące się pomiędzy Gravataí i Porto Alegre municypia Canoas (2,1 tys.) i São Leopoldo (1,2 tys.) (ryc. 8).

\section{Podsumowanie}

Rozwój przemysłu motoryzacyjnego w Brazylii, który w badanym okresie doprowadził do ponad dwuipółkrotnego wzrostu zatrudnienia w tym sektorze oraz zwiększenia mocy produkcyjnych z 2 do 4,5 mln sztuk samochodów, wiązał się z dynamicznym wzrostem zapotrzebowania na samochody na rynku krajowym oraz państw ościennych (Wójtowicz, 2012; Łasak, 2013). Tak dynamiczny rozwój przemysłu samochodowego doprowadził do wyraźnych przesunięć w jego regionalnej dystrybucji. Wiązały się one głównie z budową nowych fabryk, które zarówno koncerny działające już w Brazylii, jak i dopiero wchodzące na ten rynek lokalizowały poza starymi centrami przemysłowymi, starając się przesunąć bliżej potencjalnych rynków zbytu. Znalazło to potwierdzenie w fakcie, iż największe przemiany struktury przestrzennej odnotowano w dziale zajmującym się produkcją samochodów osobowych i lekkich dostawczych.

Drugim istotnym czynnikiem prowadzącym do przestrzennych przesunięć w strukturze rozmieszczenia przemysłu motoryzacyjnego była postępująca regionalna integracja gospodarcza w ramach Mercosur i tworzenie się regionalnych łańcuchów dostaw. Znalazło to swój wyraz w omawianym powyżej dynamicznym wzroście zatrudnienia w stanach Regionu Południowego. Dodatkowo warto podkreślić, iż w stanach tych szczególnie dynamicznie wzrosło zatrudnienie w dziale produkcji części i akcesoriów dla pojazdów samochodowych.

Wzrost zatrudnienia oraz jego przestrzenne przesunięcia doprowadziły do wyraźnego spadku koncentracji przemysłu motoryzacyjnego mierzonego wskaźnikami lokalizacji, zarówno w stosunku do powierzchni i liczby ludności, jak też w stosunku do ogólnego zatrudnienia w przemyśle przetwórczym. Warto również podkreślić, że postępująca dyspersja przestrzenna tego przemysłu wywołana była nie tylko wspomnianym powyżej przesunięciem bliżej rynku zbytu, ale stanowiła także wyraz poszukiwania miejsc oferujących najtańsze koszty produkcji, przyciągających tańszą siłą roboczą o niskim stopniu uzwiązkowienia, ulgami podatkowymi czy niskimi kosztami zakupu działki budowlanej i pomocą w jej uzbrojeniu (Rodríguez-Pose, Arbix, 2001). 
Warto również zaznaczyć, że największy (blisko czterokrotny) przyrost zatrudnienia odnotowano w przemyśle części samochodowych, co może przemawiać za rosnącym zakorzenieniem przemysłu motoryzacyjnego w Brazylii. Rozbudowa tego działu wskazuje na fakt, iż firmy samochodowe dążą do takiego rozwoju tego sektora w Brazylii, aby zapewnić sobie zestaw części i podzespołów umożliwiający pełny cykl produkcyjny bez konieczności importu spoza regionu, a także coraz większe usamodzielnienie się lokalnych oddziałów międzynarodowych firm, zarówno w kwestiach projektowania pojazdów i podzespołów, jak i ich wprowadzania na rynek krajów Mercosur (Quadros, Consoni, 2009; Salerno i in., 2009). W ostatnich latach zaczął się nowy cykl inwestycyjny. Według wstępnych deklaracji działających na tym rynku koncernów nowe inwestycje mają wynieść ponad 30 mld USD do 2015 roku, co wiąże się z oczekiwanym wzrostem chłonności brazylijskiego rynku, która ma osiągnąć 4,5 mln samochodów w 2015 roku i ponad 6 mln w 2025 roku (Ibusuki i in., 2012). W świetle powyższych prognoz i planów dalszy rozwój tego sektora w Brazylii będzie skutkował kolejnymi przesunięciami w jego rozmieszczeniu przestrzennym.

\section{Literatura \\ References}

ANFAVEA (2010, 2013). Tabelas Estatisticas, Associação Nacional dos Fabricantes de Veículos Automotores. Săo Paulo: ANFAVEA. Pozyskano z http://www.anfavea.com.br/tabelas.html

Anuário da Indústria Automobilística Brasileira 2013 (2013). Associação Nacional dos Fabricantes de Veículos Automotores. Săo Paulo: ANFAVEA.

Cavalcante, L.R., Uderman, S. (2007). The Cost of a Structural Change: A Large Automobile Plant in the State of Bahía. Latin American Business Review, 7 (3-4), 11-48. doi:10.1300/J140v07n03_02

CEMPRE (2013). Cadastro Central de Empresas - CEMPRE 1996-2011. Rio de Janeiro: Instituto Brasileiro de Geografia e Estatística - IBGE. Pozyskano z http://www.sidra.ibge.gov.br/bda/pesquisas/cempre/default.asp

Czapliński, P., Rachwał, T., Tobolska, A., Uliszak, R. (2013). Geografia gospodarcza. Przewodnik do ćwiczeń. Poznań-Kraków: Bogucki Wydawnictwo Naukowe.

Humphrey, J. (2003). Globalisation and Supply Chain Networks: The Auto Industry in Brazil and India. Global Networks, 3 (2), 121-141.

Ibusuki, U., Bernardes, R.C., Consoni, F., Saito, O.M. (2012). New Brazilian Automobile Industrial Policy (Plano Brasil Maior): risk and opportunities for the sector. $20^{\text {th }}$ GERPISA International Colloquium. Krakow. Pozyskano z http://gerpisa.org/node/1649

Laplane, M.F., Sarti, F. (1997). The Restructuring of the Brazilian Automobile Industry in the Nineties', Actes du GERPISA, 20, 31-49.

Laplane, M.F., Sarti, F. (2004). MERCOSUR: Integration between Governments and Producers and the Sustainability of the Regional Automobile Industry. W: J. Carrillo, Y. Lung, R. van Tulder (red.). Cars, Carriers of Regionalism? Houndmills-New York: Palgrave Macmillan, 121-138.

Lopes, R.L. (2007). The Automobile Industry in Paraná: The Case of Renault. Latin American Business Review, 7 (3-4), 77-96. doi: 10.1300/J140v07n03_04

Łasak, P. (2013). Nowa pozycja państw BRIC na globalnym rynku samochodowym. Studia Ekonomiczne, 2, 329-346.

Perobelli, F.S., Haddad, E.A., Bastos, S.Q. de A., Pimentel, E. (2007). Fiscal Incentives and Regional Development Projects: Mercedes-Benz in Juiz de Fora (MG)-Brazil 1996/1999. Latin American Business Review, 7 (3-4), 49-75. doi: 10.1300/J140v07n03_03 
Quadros, R., Consoni, F. (2009). Innovation capabilities in the Brazilian automobile industry: a study of vehicle assemblers' technological strategies and policy recommendations. International Journal of Technological Learning, Innovation and Development, 2 (1), 53-75.

Rachid, A., Donadone, J.C., Bento, P.E.G. (2002). New investments and industrial location: Labour qualification and organisational strategies. $10^{\text {th }}$ GERPISA International Colloquium. Paris. Pozyskano z http://gerpisa.org/rencontre/10.rencontre/papers.pdf/Rachid.pdf

Rodríguez-Pose, A., Arbix, G. (2001). Strategies of Waste: Bidding Wars in the Brazilian Automobile Sector. International Journal of Urban and Regional Research, 25 (1): 134-154. doi: $10.1111 / 1468-2427.00302$

Rodríguez-Pose, A., Tomaney, J. (1999). Industrial Crisis in the Centre of the Periphery: Stabilisation, Economic Restructuring and Policy Responses in the Sao Paulo Metropolitan Region. Urban Studies, 36 (3), 479-498. doi:10.1080/0042098993484

Rodríguez-Pose, A., Tomaney, J., Klink, J. (2001). Local empowerment through economic restructuring in Brazil: the case of the greater ABC region. Geoforum, 32 (4), 459-469. Pozyskano z http:// dx.doi.org/10.1016/S0016-7185(01)00011-2

Salerno M., Arbix, G. (2010). Economic growth, social development and crisis management: recent evolution of the auto industry in Brazil. 18 $8^{\text {th }}$ GERPISA International Colloquium. Berlin. Pozyskano z http://gerpisa.org/node/963

Salerno, M., Marx, R., Zilbovicius, M., Dias, A.V.C. (2009). The Importance of Locally Commanded Design for the Consolidation of Local Supply Chain: the Concept of Design Headquarters. International Journal of Manufacturing Technology and Management, 16 (4), 361-376.

Santos, A.M.M., Pinhão, C.M.A. (1999). Pólos Automotivos Brasileiros. BNDES Setorial, 10, 173 200. Rio de Janeiro: BNDES. Pozyskano z http://www.bndes.gov.br/SiteBNDES/export/sites/ default/bndes_pt/Galerias/Arquivos/conhecimento/bnset/set1004.pdf

Wójtowicz, M. (2008). Rozwój przemysłu samochodowego w Brazylii w latach 1957-2005. Prace Komisji Geografii Przemystu Polskiego Towarzystwa Geograficznego, 10, 140-153.

Wójtowicz, M. (2009). Wpływ globalizacji i integracji w ramach MERCOSUR na wymianę handlową produktów przemysłu samochodowego Brazylii w latach 1990-2006. Prace Komisji Geografii Przemystu Polskiego Towarzystwa Geograficznego, 12, 63-77.

Wójtowicz, M. (2012). Rozwój i przekształcenia przemysłu samochodowego w Brazylii i Meksyku na przełomie XX i XXI wieku. W: M. Drgas, J. Knopek (red.). Gospodarcze problemy Ameryki Łacińskiej. Toruń: Wydawnictwo Adam Marszałek, 161-193.

Mirosław Wójtowicz, dr, Uniwersytet Pedagogiczny w Krakowie, Instytut Geografii, Zakład Geografii Społeczno-Ekonomicznej. Doktor nauk o Ziemi w zakresie geografii (specjalność geografia społeczno-ekonomiczna), adiunkt w Zakładzie Geografii Społeczno-Ekonomicznej Uniwersytetu Pedagogicznego w Krakowie. Jego zainteresowania badawcze koncentrują się wokół zagadnień procesów urbanizacji oraz industrializacji w Ameryce Łacińskiej, ze szczególnym uwzględnieniem Argentyny, Brazylii i Meksyku.

Mirosław Wójtowicz, holds a Ph.D. title in Earth Sciences in the field of Geography (specialization - Socio-Economic Geography). He is an assistant professor in the Department of Socio-Economic Geography at the Pedagogical University of Cracow. His research interests focus on issues of urbanization and industrialization processes in Latin America, with particular emphasis on Argentina, Brazil and Mexico.

\section{Adres/address:}

Uniwersytet Pedagogiczny w Krakowie

Instytut Geografii

Zakład Geografii Społeczno-Ekonomicznej

ul. Podchorążych 2, 30-084 Kraków, Polska

e-mail: mwojt@up.krakow.pl 